\title{
AN ANALYTIC THEOLOGIAN'S STANCE ON THE EXISTENCE OF GOD
}

\author{
BENEDIKT PAUL GÖCKE
}

Ruhr-Universität Bochum

\begin{abstract}
The existence of God is once again the focus of vivid philosophical discussion. From the point of view of analytic theology, however, people often talk past each other when they debate about the putative existence or nonexistence of God. In the worst case, for instance, atheists deny the existence of a God, which no theists ever claimed to exist. In order to avoid confusions like this we need to be clear about the function of the term 'God' in its different contexts of use. In what follows, I distinguish between the functions of 'God' in philosophical contexts on the one hand and in theological contexts on the other in order to provide a schema, which helps to avoid confusion in the debate on the existence or non-existence of God.
\end{abstract}

\section{INTRODUCTION}

A fundamental question of metaphysical speculation concerns the existence of God. In order to answer it philosophers do not hesitate to point to the numerous arguments for and against the existence of God that have been developed and evaluated throughout the history of mankind. Often, however, too little reflection is directed upon what the arguments actually show, and upon how their conclusions or premises logically relate to the deployed concept of God. In what follows, I firstly provide a brief analysis of the argumentative structure of so-called arguments for the existence of God and then argue that the term 'God' is not a genuine philosophical but a theological concept philosophers could entirely dispense with since philosophy is only interested in questions concerning the ultimate ground of reality - in whichever way we have to characterise this ground within the metaphysical paradigm we deploy. ${ }^{1}$ 
In a second step I argue that it is theology that has a genuine interest to show that her concept of God is philosophically confirmed as the adequate concept of the ultimate ground of reality, whereas the adequacy of the theological concept of God originates primarily out of scriptural and not out of philosophical considerations. The question of whether God exists, then, according to its form, is the question of whether the best philosophical account of the ultimate ground of reality confirms the existence of what the theologians call 'God'. Consequently, in the framework developed, the proper context of use of so-called arguments against the existence of God is not a philosophical but a genuine theological one: arguments against the existence of God are arguments according to which there is a mismatch between philosophical accounts of the ultimate ground of reality and a particular theological conception of the divine that happens to function like an account of the ultimate ground of reality.

\section{THE FUNCTION OF 'GOD’ IN PHILOSOPHY}

As with arguments in other fields of philosophy, arguments for the existence of God can be classified by twice deploying a twofold distinction: they can be classified according to the way their premises are justified and also according to the way in which the alleged truth of the premises transfers truth on the conclusion of the argument. If at least one of the premises is justified by way of our experience of the world, the argument is called a posteriori. If each premise is justified independent from experience, it is an a priori argument. If it is not possible that the premises are true and the conclusion false, then the argument is a deductive one. If the truth of the premises does not entail the truth of the conclusion of the argument but nevertheless bestows a reasonable probability of being true on it, then the argument is an inductive one. In what follows, I focus only on so-called deductive arguments for the existence of God. ${ }^{2}$

The most popular deductive arguments for the existence of God are the 'Five Ways' of Thomas Aquinas and the so-called 'Ontological

1 I use 'concept', 'notion', and 'conception' interchangeably. For an account that distinguishes between concepts and conceptions of God cf. Herrmann (2008).

2 The argument to come applies to deductive arguments as well as to inductive arguments for the existence of God. Cf. Swinburne (2004) for an inductive argument for the existence of God. 
Arguments' suggested by Anselm from Canterbury. The Five Ways are a posteriori; the Ontological Argument is a priori.

Saint Thomas states his Five Ways as follows, and although knowledge of them is common, it is worth quoting them in length:

The existence of God can be proved in five ways. The first and more manifest way is the argument from motion. It is certain, and evident to our senses, that in the world some things are in motion. Now whatever is in motion is put in motion by another. (...) If that by which it is put in motion be itself put in motion, then this also must needs be put in motion by another, and that by another again. But this cannot go on to infinity, because then there would be no first mover, and, consequently, no other mover (...) Therefore it is necessary to arrive at a first mover, put in motion by no other; and this everyone understands to be God.

The second way is from the nature of the efficient cause. In the world of sense we find there is an order of efficient causes. There is no case known (neither is it, indeed, possible) in which a thing is found to be the efficient cause of itself; for so it would be prior to itself, which is impossible. Now in efficient causes it is not possible to go on to infinity, because in all efficient causes following in order, the first is the cause of the intermediate cause, and the intermediate is the cause of the ultimate cause, whether the intermediate cause be several, or only one. Now to take away the cause is to take away the effect. Therefore, if there be no first cause among efficient causes, there will be no ultimate, nor any intermediate cause. (...) Therefore it is necessary to admit a first efficient cause, to which everyone gives the name of God.

The third way is taken from possibility and necessity, and runs thus. We find in nature things that are possible to be and not to be, since they are found to be generated, and to corrupt, and consequently, they are possible to be and not to be. But it is impossible for these always to exist, for that which is possible not to be at some time is not. Therefore, if everything is possible not to be, then at one time there could have been nothing in existence. Now if this were true, even now there would be nothing in existence, because that which does not exist only begins to exist by something already existing. Therefore, if at one time nothing was in existence, it would have been impossible for anything to have begun to exist; and thus even now nothing would be in existence - which is absurd. Therefore, not all beings are merely possible, but there must exist something the existence of which is necessary. (...) Therefore we cannot but postulate the existence of some being having of itself its own necessity (...) This all men speak of as God. 
The fourth way is taken from the gradation to be found in things. Among beings there are some more and some less good, true, noble and the like. But 'more' and 'less' are predicated of different things, according as they resemble in their different ways something which is the maximum, as a thing is said to be hotter according as it more nearly resembles that which is hottest; so that there is something which is truest, something best, something noblest and, consequently, something which is uttermost being; for those things that are greatest in truth are greatest in being(...) Now the maximum in any genus is the cause of all in that genus; as fire, which is the maximum heat, is the cause of all hot things. Therefore there must also be something which is to all beings the cause of their being, goodness, and every other perfection; and this we call God.

The fifth way is taken from the governance of the world. We see that things which lack intelligence, such as natural bodies, act for an end, and this is evident from their acting always, or nearly always, in the same way, so as to obtain the best result. Hence it is plain that not fortuitously, but designedly, do they achieve their end. Now whatever lacks intelligence cannot move towards an end, unless it be directed by some being endowed with knowledge and intelligence; as the arrow is shot to its mark by the archer. Therefore some intelligent being exists by whom all natural things are directed to their end; and this being we call God. (Aquinas: Summa Theologica, Prima Pars Q2A3)

The argumentative structure of these arguments is as follows: firstly, a premise concerning a fundamental phenomenon of the world is stated and justified by way of reliance on our experience of the world, let's call this kind of premise the experiential base of the argument. ${ }^{3}$ Secondly, further premises provide a conceptual and metaphysical analysis of the phenomenon in question according to which it could not exist unless there is a certain ultimate ground with features sufficient to explain the existence of the phenomenon in question; let us call these premises the conceptual base, or the metaphysical paradigm of the argument. Thirdly, it is concluded deductively that given the experiential and the conceptual base of the argument it follows that the ultimate ground specified in the conceptual base has to exist. Fourthly, it is announced that we call this

${ }^{3}$ When I speak about the logic of these arguments, what I have in mind is their argumentative structure, and not a particular formalisation of these arguments. For different formalisations of these arguments, and their corresponding problems, cf. Ricken (1998) and Sobel (2004). 
ultimate ground 'God', let us call this kind of announcement the act of baptism of the argument.

Given the distinction between the experiential base, the conceptual base, and the act of baptism, we can structure the Five Ways roughly as follows. The experiential base is: (1) There is motion in the world, (2) there is efficient causation in the world, (3) there is possibility in the world, (4) there is gradation in the world, and (5) there is governance of unintelligent beings in the world. The conceptual base is as follows: (1a) whatever is in motion must be put in motion by another and this cannot be an actually infinite series, (2a) whatever is an efficient cause needs another efficient cause and this series cannot be actually infinite, (3a) if each entity possibly does not exist, then there is a time when nothing exists which entails that nothing could exist now, (4a) graduation is possible only if there is maximal realisation of what is graduated, and (5a) governance of unintelligent beings entails that there is something directing these beings. Deductively based upon their experiential and conceptual base, the arguments generate the following conclusions, respectively: ( $1 \mathrm{~b})$ there is an unmoved mover, $(2 \mathrm{~b})$ there is an uncaused cause, (3b) there is a necessary being, (4b) there is a maximal realisation of every perfection, and (5b) there is a being which directs all unintelligent beings to their end. Each conclusion is followed by a corresponding act of baptism, according to which this is what everybody calls God, or refers to as 'God' or understands to be God.

There are at least two problems with these so-called arguments for the existence of God. The first problem is intrinsic to each argument if it is understood to be an argument for the existence of God; the second problem emerges once the Five Ways are seen in total.

The intrinsic problem of each of the Five Ways is that none of them actually concludes by way of asserting the existence of God. Their philosophical conclusions are much more decent. Once the philosophical work is done, they only conclude that there is an unmoved mover, respectively an uncaused cause, respectively a final cause upon which all is directed, etc. The term 'God' comes into play only in the act of baptism, which from a logical point of view is an arbitrary addendum to the argument, and not part of the argument itself insofar as its logical structure is concerned. ${ }^{4}$

${ }^{4}$ Cf. also Meixner (2012: 175): 'Nothing in Thomas Aquinas's argument (...) justifies the conclusion that this agent which is a first cause is God or even a god.' Cf. also Meixner (2009: 34). 
The extrinsic problem comes into focus once we consider the Five Ways in sum. Since Thomas deploys the same act of baptism at the end of each of his ways, he generates the impression that of necessity the unmoved mover has to be the uncaused cause, has to be a necessary being, has to be the final goal of nature, has to be maximal perfection. However, without further philosophical argument one is justified to doubt whether it is really the existence of one and the same entity that all these arguments point to if what is established, if they are sound, is only that there is an unmoved mover and an uncaused cause, etc. Thomas would have needed an argument that of necessity the uncaused cause is the unmoved mover, etc., in order to persuade philosophers that there is reference to exactly one entity in the Five Ways.

Let us turn to Anselm's 'ontological arguments' and analyse their argumentative structure. Anselm states them as follows:

And so, LorD, do thou, who dost give understanding to faith, give me, so far as thou knowest it to be profitable, to understand that thou art as we believe; and that thou art that which we believe. And indeed, we believe that thou art a being than which nothing greater can be conceived. Or is there no such nature, since the fool hath said in his heart, there is no God? (Psalms 14:1). But, at any rate, this very fool, when he hears of this being of which I speak - a being than which nothing greater can be conceived - understands what he hears, and what he understands is in his understanding; although he does not understand it to exist. For, it is one thing for an object to be in the understanding, and another to understand that the object exists. (...) Hence, even the fool is convinced that something exists in the understanding, at least, than which nothing greater can be conceived. For, when he hears of this, he understands it. And whatever is understood, exists in the understanding. And assuredly that, than which nothing greater can be conceived, cannot exist in the understanding alone. For, suppose it exists in the understanding alone: then it can be conceived to exist in reality; which is greater. Therefore, if that, than which nothing greater can be conceived, exists in the understanding alone, the very being, than which nothing greater can be conceived, is one, than which a greater can be conceived. But obviously this is impossible. Hence, there is no doubt that there exists a being, than which nothing greater can be conceived, and it exists both in the understanding and in reality.

God cannot be conceived not to exist. God is that, than which nothing greater can be conceived. That which can be conceived not to exist is not 
God. And it assuredly exists so truly, that it cannot be conceived not to exist. For, it is possible to conceive of a being, which cannot be conceived not to exist; and this is greater than one which can be conceived not to exist. Hence, if that, than which nothing greater can be conceived, can be conceived not to exist, it is not that, than which nothing greater can be conceived. But this is an irreconcilable contradiction. There is, then, so truly a being than which nothing greater can be conceived to exist, that it cannot even be conceived not to exist; and this being thou art, O LoRD, our God. (Anselm: Proslogion, Ch. 2 \& 3)

The argumentative structure of these arguments is as follows: firstly, a stipulative definition of the term 'God' is provided and specified in terms of a definite description; let us call this the definition base of the argument. Secondly, conceptual and metaphysical reflections are spelled out according to which one obtains a contradiction if one assumes that there is no such entity as specified in the definition; let us call this kind of premises again the conceptual base, respectively the metaphysical paradigm of the argument. Thirdly, it is concluded that given the definition base and the conceptual base, it is true that 'God exists' since the entity specified in the definition base of the argument exists.

Deploying the distinction between the definition base and the conceptual base we can structure both of Anselm's ontological arguments as follows. The definition base of both is this: the term 'God' is synonymous with the definite description 'that than which a greater cannot be imagined. The conceptual base of the first ontological argument is: (1) that than which a greater cannot be imagined has to exist because otherwise it would not be that than which a greater cannot be imagined. The conceptual base of the second argument is: (2) that than which a greater cannot be imagined has to exist of necessity since something that cannot lack existence is greater than something that can lack existence. The conclusion of the first argument is that given the definition base of the argument it is true to assert that 'God exists', and the conclusion of the second is a modal intensification according to which it is true that 'God exists necessarily'.

Ontological arguments suffer from the same intrinsic problem as the mentioned a posteriori arguments. ${ }^{5}$ The genuine philosophical job is done without need of or reference to the concept of God. The only

${ }_{5}$ Unlike the Five Ways, they are not subject to an extrinsic problem since both ontological arguments are based on the same definition base. 
important phrase is 'that, than which a greater cannot be conceived'. However, in contrast to the analysed a posteriori arguments, where from a logical point of view the act of baptism is an arbitrary addition at the end of the argument, a priori arguments proceed the other way about and start with the definition base, which like the act of baptism of the Five Ways is not a proper part of the philosophical argument as such. The argument, if sound, only shows that there is that than which a greater cannot be conceived - as such it is independent of 'God'.

What we said about the argumentative structure of the most popular a posteriori and a priori arguments for the existence of God mutatis mutandis applies to any so-called philosophical argument for the existence of God.

Firstly, any a posteriori argument of necessity implicitly or explicitly has the following logical form: (1) Experiential Base, (2) Conceptual Base, (3) Conclusion, (4) Act of Baptism. For instance, take the argument from fine-tuning. Roughly, the experiential base asserts that the universe is fine-tuned, while the metaphysical paradigm of the argument firstly states that the fine-tuning of the universe is due to physical necessity, chance, or a designer and then proceeds to argue that neither physical necessity nor chance can reasonably account for the fine-tuning of the universe. The conclusion states that, therefore, there is a designer of the universe. Finally, the act of baptism stipulates that the designer is what we call 'God'.

Secondly, as regards so-called a priori arguments for the existence of God, the general argumentative structure is as follows: (1) Definition Base, (2) Conceptual Base, (3) Conclusion. Take, for instance, a look at Descartes' ontological argument:

But if the mere fact that I can produce from my thought the idea of something entails that everything which I clearly and distinctly perceive to belong to that thing really does belong to it, is not this a possible basis for another argument to prove the existence of God? Certainly, the idea of God, or a supremely perfect being, is one that I find within me just as surely as the idea of any shape or number. And my understanding that it belongs to his nature that he always exists is no less clear and distinct than is the case when I prove of any shape or number that some property belongs to its nature. (Descartes 1996: 45) ${ }^{7}$

${ }^{6}$ For more on the argument from fine-tuning cf. Monton (2006). In general, any arbitrarily chosen a posteriori argument for the existence of God can be stated in such a way that it exhibits the mentioned argumentative form. 
The definition base of the argument is that 'God' is an abbreviation for 'a supremely perfect being'. The conceptual base firstly asserts that everything, which clearly and distinctively is perceived to belong to the idea of a supremely perfect being, also belongs to it in reality. The conceptual base then goes on to argue that existence is perceived to belong to the idea of a supremely perfect being, which is why the conclusion states that since a supremely perfect being exists, it is true to assert 'God exists.'

Therefore, as far as the structure of so-called arguments for the existence of God is concerned, we can conclude the following: firstly, philosophy could entirely dispense with the concept of God without losing any of its genuine argumentative force. The reason, as we have shown, is that in a philosophical context 'God' is either just a name amongst other names of which in an act of baptism we have to decide how to deploy, or else is used as an abbreviation for a particular definite description as specified in the definition base of the corresponding argument. ${ }^{9}$ Since philosophy is neither interested in acts of baptism nor in stipulative definitions of particular terms, we could simply dispense with 'God'. Secondly, however, instead of deleting the term 'God' we could also explicitly identify its philosophical function as an unrestricted semantic placeholder for whatever it is that our respective metaphysical paradigm commits us to assume as regards the nature of the ultimate ground of reality. ${ }^{10}$

According to this option, the meaning of the assertion 'God exists' is a function of the metaphysical paradigm in which it is stated and consequently can express different views about the ultimate ground of reality in dependence of the paradigm in which it is expressed. In other words, in a philosophical context, the assertion that 'God exists' means

${ }^{7}$ Cf. Wee (2012) for further analysis of this argument.

${ }^{8}$ In general, any arbitrarily chosen a priori argument for the existence of God can be stated in such a way that it exhibits the mentioned argumentative form.

9 This can be nicely observed in the passage quoted from Descartes, where he says: 'the idea of God, or a supremely perfect being.' The argument could entirely be stated without reference to the term 'God' since it is concerned only with the existence of a supremely perfect being.

${ }^{10}$ This use of the term 'God' is what I take Fischer to mean when he says, 'I assume that the term "God" is a descriptive expression used to mark a certain role, rather than a proper name' (Fischer 1989: 87). It also fits with the observation of Milem, when he states the following: 'Reason finds itself standing before a mystery, the cause of everything that exists, and gives this mystery the name "God"' (Milem 2007: 86). 
nothing over and above 'In the metaphysical paradigm $\mathrm{X}$, the ultimate ground of reality is Y'. The assertion 'God exists' thus is always a cypher for a particular Weltanschauung.

For instance, without the act of baptism, the Five Ways of Thomas precisely have the function of philosophical arguments that are directed at an illumination of the ultimate ground of reality, an explanation, which is based on our experience of the world and the metaphysical paradigm within which Thomas was operating. Therefore, when Thomas asserts 'God exists', what he expresses is a particular conception of the ultimate ground of reality based on certain metaphysical assumptions like the impossibility of an actual infinitude. In contrast, when, say, Leibniz asserts that 'God exists', then he expresses a different account of the ultimate ground of reality, since he did not assume that an actual infinitude is impossible (cf. Laerke 2011). It is a great source of confusion if one is not aware of the fact that the assertion 'God exists' expresses entirely different accounts of the ultimate ground of reality in different contexts and instead treats the concept of God independent from the philosophical context out of which it once originated.

In sum, our analysis of so-called arguments for the existence of God showed that in reference to their argumentative structure, 'God' is either introduced in an act of baptism for the entity specified in the conclusion of the argument or else is stipulated as an abbreviation for a certain definite description. Arguments for the existence of God could dispense with the term 'God' without losing any of their genuine philosophical force as arguments concerning the ultimate ground of reality. If the term 'God' is nevertheless deployed in philosophical discussions, one has to be aware that it functions like an unrestricted semantic placeholder for whatever it is that the metaphysical paradigm deployed commits us to assume as regards the nature of the ultimate ground of reality.

\section{THE FUNCTION OF ‘GOD’ IN THEOLOGY}

We have analysed the function of the term 'God' in so-called philosophical arguments for the existence of God. However, philosophy is only a secondary context in which 'God' figures as a prominent role. Primarily, 'God' is a theological notion that originated in the religious life of early human societies, and consequently has its own traditional use and development independent from philosophy. ${ }^{11}$ 
In Western theological tradition, what we mean by 'God' is closely related to what we understand the Bible to say about God. ${ }^{12}$ It would be ideal if the Bible provided a neat and clear-cut definition of God so that we could in principle replace any Biblical mentioning of God with such a definition salva veritate. Unfortunately, this is an idle dream: in the discussion of these matters, we tend to forget the fact that the monotheistic conception of God that the Bible deals with is by no means a monolithic one. ${ }^{13}$ Jewish, and therefore Christian monotheism in fact started as a monolatrism that entailed philosophical polytheism and it was not before the time of Deuteroisaiah that an explicit monotheism was established as part of the theological reaction to the Babylonian Exile. Therefore, there is no single complete and unanimous conception of God that is intrinsically and unambiguously based on Scripture. The books of Scripture themselves reflect a process of clarifying what is or could be meant by the term 'God.' ${ }^{14}$

However, although there is no such clear-cut conception to be found, after all, the Bible is no philosophical disputation but a history of salvation, what theologians can positively agree upon is a minimal consensus that the God of the Bible has certain features which of necessity belong to any theologically adequate concept of God - regardless its further qualification.

The problem is to decide which elements exactly belong to the minimal consensus of a conception of God based on Scripture. Since there could be an absolutely adequate decision procedure in order to decide which parts of necessity belong to the minimal conception of God if and only if we had a prior and independent grasp on the God of the Bible with which to compare scripture as regards its adequacy concerning the 'proper' use of the term 'God' in a theological context,

${ }^{11}$ Cf. Puntel (2008: 447): “God” is originally not a philosophical concept, but a term arising in religions, and one with which many in part quite heterogeneous ideas have been and continue to be connected.'

${ }^{12}$ I bracket other religious traditions like Islamic or Hindu traditions. The same kind of consideration, however, applies to these traditions as well insofar as they base their religious conceptions of God on revealed written or oral treatments of what they call 'God'.

${ }^{13}$ As Craig (2009: 71) says: 'The concept of God is underdetermined by the biblical data.' Apart from this difficulty, we also tend to forget that the phrase 'the Bible' in different Christian Denominations refers to different corpi of revealed books and texts.

${ }^{14}$ For more on the development of monotheism in Ancient Israel cf. Keel (1980), Lang (1981), Wacker (1999), and Becking et al. (2001). 
it seems that our best means to establish a certain minimal consensus as regards the conception of God to be found in the Bible is by way of exegetical analysis of what the texts actually say. ${ }^{15}$

Although there is no room to develop this fully in the present paper, it seems to be plausible to agree that a minimal consensus at least entails the following: the God of the Bible is supposed to be worthy of worship, supposed to be the creator of all that is, and supposed to share a deep and loving relationship with his creation that He wants to be saved. ${ }^{16}$ Any theological notion of God, which does not agree upon this minimal consensus, seems to be religiously and exegetically inadequate right from the start as a theological concept of the God of whom the Bible speaks.

The minimal consensus is silent on many features, which we are used to associating with the God of the Bible. For instance, the minimal consensus is silent on the questions of whether the Bible assumes that God is everlasting or eternal, immutable or able to change. It is silent on these matters because there is Scriptural evidence for each of these assumptions, which is to say that the minimal consensus can be extended in different, more fully developed concepts of God that are equally based on Scripture but might contradict each other. In what follows, I deploy the term 'God' in such a way that it only refers to what is specified in the minimal consensus in order to avoid confusion.

15 According to Alston 'experiential awareness of God, or as I shall be saying, the perception of God, makes an important contribution to the grounds of religious belief. More specifically, a person can become justified in holding certain kinds of beliefs about God by virtue of perceiving God as being or doing so-and-so' (Alston 1991: 1). One could argue that there is no need for an exegetical account of the concept of God since it is possible to perceive God as being so-and-so. However, this seems to me to be problematic since one could always doubt that what is perceived is really the God of the Bible. As Kaufman says, 'in the monotheistic perspective, human beings do not live simply suspended before their creator, as it were, in direct and continuous face-to-face interaction with God' (Kaufman 1981: 111).

${ }^{16}$ It is unclear whether there can be an adequate clarification of the conditions necessary and sufficient to be an 'object' worthy of worship, which at the same time grounds in Scripture and philosophical argument about what it means to be worthy of worship. If the God of the Bible could simply be understood to be an object worthy of worship, whereas the analysis of what it is to be an object worthy of worship is achieved purely by philosophical means, then the Bible is simply pointless as regards the qualification of God insofar as he is factually described in Scripture. The problem is that from a philosophical point of view one quickly arrives at the conclusion that an object worthy of worship has to be the perfect being, which has all its qualities essentially and necessarily. Cf. Findlay (1955: 52-3). 
As regards the function of 'God' in a purely theological context, we can state the following: Firstly, 'God' functions as a name for the deity which revealed itself firstly to the tribes of Israel and then revealed itself in Jesus Christ to all of mankind, whereas Scripture and the history of the tribes of Israel are taken to be sufficient evidence for the existence of this deity. Although it might be unclear how to specify further exegetically the minimal consensus as regards the concept of God deployed in the Bible, there is no genuine theological discussion about whether this deity exists or not. It is a necessary presumption of theology to assume that the God of whom the Bible speaks exists.

However, secondly, although in a purely theological context, 'God' functions like a name, the minimal consensus which theology spells out in the description of this deity also has the form of a genuine philosophical account of the ultimate ground of reality. Now, Tertullian once asked, 'What has Athens to do with Jerusalem? Or the Academy with the Church?' (Tertullian: De Praescriptione vii). From a systematic point of view, the answer is as follows: as such Athens has nothing to do with Jerusalem. However, Jerusalem happens to possess something that has the form of a philosophical account of the ultimate ground of reality and therefore is eo ipso interesting to the Academy, particularly given that the way Jerusalem obtained this account is based primarily on revelation and not on philosophical argument. That is to say, the way the theological concept of 'God' enters philosophical territory is asymptotic to the nature of philosophy since whatever is known about the God of the Bible is supposed to be known primarily through divine revelation and not through philosophical argument.

In the very moment in which theology enters philosophical discussion, it also constitutes the very intelligibility of atheism. Whenever there is a particular conception of God of which the theologian says that it is an adequate scriptural understanding of the God of the Bible, then it is eo ipso possible that philosophy rejects such a theological notion of God as an adequate notion of the ultimate ground of reality. Based on this understanding, so-called arguments against the existence of God are arguments according to which there is a mismatch between a theological notion of God and the philosophical account of the ultimate ground of reality.

For instance, suppose that the theologian argues that Scripture confirms that the God of the Bible, in addition to what is specified in the minimal consensus, is also omnipotent, omniscient and morally perfect. 
Given this understanding of the term 'God', philosophers argue that if 'God' is meant to mean this, then there could be no evil in the world. Since, however, there is evil in this world, the philosopher concludes that 'God' thus understood is not an adequate account of the ultimate ground of reality, and that therefore it is true to assert that 'God does not exist.'. ${ }^{17}$

In situationslikethese, given the soundness of the respective arguments, the theologian has two options how to react. Either the theologian argues that the attacked conception of God is in fact adequately based on Scripture and is the only adequate interpretation or he argues that precisely those features of the theological conception of God that lead to a contradiction with a philosophical account of the ultimate ground of reality do not of necessity belong to the theological concept of God.

If the theologian supposes that the conception of God under attack is the only adequate understanding of 'God', then atheism or religious fundamentalism are the reactions to follow. Atheism on side of the philosophers because one is justified to assert that God (as qualified) does not exist. Religious fundamentalism follows on side of the theologian because he assumes to possess an ultimate truth based on Scripture, which contradicts human reason. Neither consequence is desirable. Since we have already seen above that there is no single and unambiguous clear-cut definition of God based on Scripture, the reasonable theologian should opt for the second option.

Choosing the second option, the theologian has to be open minded and accept that any concept of God, which goes beyond the minimal consensus, might always be open to revision. However, given that Scripture itself shows a development and change in the concept of God, this does not seem to be too much of a problem. The only move the theologian cannot make is to reject elements that belong to the minimal consensus of the theological notion of God, which is to say that the only strictly atheistic argument would be an argument that the ultimate ground of reality cannot be a loving creator that wants us to be saved. ${ }^{18}$

17 Cf. Mackie: 'In its simplest form the problem is this: God is omnipotent; God is wholly good; and yet evil exists. There seems to be some contradiction between these three propositions, so that if any two of them were true the third would be false. But at the same time all three are essential parts of most theological positions: the theologian, it seems, at once must adhere and cannot consistently adhere to all three.' (Mackie 1955: 200)

${ }^{18}$ I have to confess that I have not the slightest idea how such an argument could look like. Certainly, arguments from evil will not do the job since the theological notion of God is, as far as I can see, simply consistent with there being evil in the world. 
In sum, the function of 'God' in a purely theological context is to serve as a name that refers to the God of whom the Bible speaks, whereas exegetical analyses of Scripture specify a minimal consensus of the qualities we have to assume to belong to the God of the Bible. The theological concept of God enters philosophical discourse because it happens to be an account of the ultimate ground of reality which is reached at through revelation and not philosophical argument. Arguments against the existence of God are arguments according to which there is a mismatch between theological notions of God and philosophical accounts of the ultimate ground of reality.

\section{A SCHEMA TO AVOID CONFUSION}

We have reached the following conclusions: Firstly, philosophy can entirely dispense with the term 'God' since it is an unrestricted semantic placeholder for the ultimate ground of reality. Secondly, theology specifies particular concepts of God based on an interpretation of Scripture, whereas there is a minimal consensus as regards the meaning of 'God' as a theological term. Arguments for the existence of God are arguments that show that the theological and intrinsically non-philosophical notion of the God of the Bible in fact coheres with the philosophical account of the ultimate ground of reality. Arguments against the existence of God are arguments according to which the theological concept of God does not correspond with our knowledge of the ultimate ground of reality.

In order to avoid confusion in our discussions about the existence or non-existence of God, the following schema is of some help:

(1) If somebody asserts that 'God exists', then it needs to be clarified whether (a) he deploys a philosophical concept of God as a placeholder for the ultimate ground of reality which he calls 'God' or whether (b) he deploys a theological concept of God based on Scripture.

If (a), then 'God exists' can be translated into a proposition, which does not deploy the term 'God' but specifies an account of the ultimate ground of reality. The philosophically interesting questions here are whether the argument proposed to arrive at the suggested conception of the ultimate ground is sound and whether the metaphysical paradigm in which it is stated is plausible itself.

If (b), then the statement 'God exists' can be translated into a proposition, which does not deploy the term 'God' but specifies at least a minimal consensus of what is meant by 'God' given scriptural evidence. 
In this case, the first question to be discussed is whether the suggested theological surrogate for the term 'God' is adequately based on Scripture. If it is not, then this particular assertion that 'God exists' is irrelevant from a theological point of view. The second question to be discussed is whether the philosophical account of the ultimate ground confirms the existence of what the theologians call 'God'.

(2) If somebody asserts 'God does not exist', then it needs to be clarified whether $\left(\mathrm{a}^{*}\right)$ he deploys a philosophical concept of God as a placeholder for the ultimate ground of reality, which he calls 'God' or whether $\left(b^{*}\right)$ he deploys a theological concept of God based on Scripture.

If $\left(\mathrm{a}^{*}\right)$, then 'God does not exist' can be translated into a proposition, which does not deploy the term 'God' but specifies a denial of a particular account of the ultimate ground of reality. The philosophically interesting questions then are whether the argument proposed to arrive at this denial is sound and whether the metaphysical paradigm in which it is stated is plausible itself.

If $\left(b^{*}\right)$, then the statement 'God does not exist' can be translated into a proposition, which does not deploy the term 'God' but specifies at least a minimal consensus of what is meant by 'God' given scriptural evidence. In this case, the first question that has to be discussed is whether the suggested theological surrogate for the term 'God' is adequately based on Scripture. If it is not adequately based on Scripture, then the corresponding assertion 'God does not exist' is without any rationale in itself. If, however, it is adequately based on Scripture, then the interesting questions are whether the argument to arrive at the conclusion that the ultimate ground cannot have the features of the God of the Bible is sound and whether the metaphysical paradigm in which it is stated is plausible itself. ${ }^{19}$

\section{BIBLIOGRAPHY}

Alston, William P. 1991. Perceiving God. The Epistemology of Religious Experience (London: Cornell University Press)

Anselm. 1983. 'Proslogion', in Classical Readings in Christian Apologetics: A.D. 100-1800, edited by L. Russ Bush (Grand Rapids, Mich.: Zondervan), pp. 252-53

${ }^{19}$ Acknowledgement: Research for this publication was made possible through the support of the grant 'Analytic Theology' from the John Templeton Foundation. 
Becking, Bob, Meindert Dijkstra, and Marjo Korpel (eds.). 2001. Only One God? Monotheism in Ancient Israel and the Veneration of the Goddess Asherah (Sheffield: Sheffield Academic Press)

Craig, William Lane. 2009. 'Theistic Critiques of Atheism', in The Cambridge Companion to Atheism, edited by M. Martin (Cambridge: Cambridge University Press), pp. 69-85

Descartes, René. 1996. Meditations on First Philosophy with Selections from the Objections and Replies, edited by John Cottingham (Cambridge: Cambridge University Press)

Fischer, John Martin. 1989. 'Freedom and Foreknowledge', in God, Foreknowledge, and Freedom, edited by J. M. Fischer (Stanford: Stanford University Press), pp. 86-96

Findlay, J. N. 1955. 'Can God's Existence be Disproved?', in New Essays in Philosophical Theology, edited by A. Flew and A. MacIntyre (London: SCM Press), pp. 47-56

Herrmann, Eberhard. 2008. 'On the Distinction Between the Concept of God and Conceptions of God', in International Journal for Philosophy of Religion, Vol. 64: 63-73

Kaufman, Gordon. 1981. The Theological Imagination: Constructing the Concept of God (Philadelphia, Pennsylvania: Westminster John Knox Press)

Keel, Othmar (ed.). 1980. Monotheismus im Alten Israel und seiner Umwelt (Fribourg: Verlag Schweizerisches Katholisches Bibelwerk)

Laerke, Mogens. 2011. 'Leibniz's Cosmological Argument for the Existence of God', in Archiv für Geschichte der Philosophie, Vol. 93: 58-84

Lang, Bernhard (ed.). 1981. Der einzige Gott. Die Geburt des biblischen Monotheismus (München: Kösel)

Mackie, J. L. 1955. 'Evil and Omnipotence', in Mind, Vol. 64: 200-212

Meixner, Uwe. 2009. 'Three Indications for the Existence of God in Causal Metaphysics', in International Journal for Philosophy of Religion, Vol. 66: 33-46

Meixner, Uwe. 2012. 'A Cosmo-Ontological Argument for the Existence of a First Cause - Perhaps God', in European Journal for Philosophy of Religion, Vol. 4: 169-178

Milem, Bruce. 2007. 'Turner on Reason and Proving God's Existence', in Philosophy and Theology, Vol. 19: 79-94

Monton, Bradley. 2006. 'God, Fine-Tuning, and the Problem of Old Evidence', in British Journal for the Philosophy of Science, Vol. 57: 405-424

Puntel, Lorenz Bruno. 2008. Structure and Being: A Theoretical Framework for a Systematic Philosophy (University Park: The Pennsylvania State University Press)

Ricken, Friedo (ed). 1998. Klassische Gottesbeweise in der Sicht der gegenwärtigen Logik und Wissenschaftstheorie (Stuttgart: Kohlhammer) 
Sobel, Jordan Howard. 2004. Logic and Theism. Arguments for and Against Beliefs in God (Cambridge: Cambridge University Press)

Swinburne, Richard. 2004. The Existence of God (Oxford: Oxford University Press)

Tertullian. De praescriptione haereticorum (Lateinisch-Deutsch), übersetzt und eingeleitet von Dietrich Schleyer (Turnhout: Brepols)

Thomas Aquinas. 1920. The Summa Theologica of St. Thomas Aquinas, Second and Revised Edition. Literally translated by Fathers of the English Dominican Province

Wacker, Marie-Theres. 1999. 'Der biblische Monotheismus - seine Entstehung und seine Folgen', in Religiosität am Ende der Moderne, edited by Heinrich Schmidinger (Innsbruck: Wein), pp. 51-92

Wee, Cecilia. 2012. 'Descartes's Ontological Proof of God's Existence', in British Journal for the History of Philosophy, Vol. 20: 23-40 